University of Nebraska - Lincoln

DigitalCommons@University of Nebraska - Lincoln

Nebraska Beef Cattle Reports

Animal Science Department

2011

\title{
Winter Grazing System and Supplementation of Beef Cows During Late Gestation Influence Heifer Progeny
}

\author{
Richard N. Funston \\ University of Nebraska-Lincoln, rfunston2@unl.edu \\ Jeremy L. Martin \\ University of Nebraska-Lincoln \\ Adam F. Summers \\ University of Nebraska-Lincoln, adamfsummers@gmail.com \\ Don Adams \\ University of Nebraska-Lincoln, dadams1@unl.edu \\ Jacqueline Musgrave \\ University of Nebraska-Lincoln, jmusgrave1@unl.edu
}

See next page for additional authors

Follow this and additional works at: https://digitalcommons.unl.edu/animalscinbcr

Part of the Animal Sciences Commons

Funston, Richard N.; Martin, Jeremy L.; Summers, Adam F.; Adams, Don; Musgrave, Jacqueline; Meyer, T. L.; and Larson, Daniel M., "Winter Grazing System and Supplementation of Beef Cows During Late Gestation Influence Heifer Progeny" (2011). Nebraska Beef Cattle Reports. 609.

https://digitalcommons.unl.edu/animalscinbcr/609

This Article is brought to you for free and open access by the Animal Science Department at DigitalCommons@University of Nebraska - Lincoln. It has been accepted for inclusion in Nebraska Beef Cattle Reports by an authorized administrator of DigitalCommons@University of Nebraska - Lincoln. 


\section{Authors}

Richard N. Funston, Jeremy L. Martin, Adam F. Summers, Don Adams, Jacqueline Musgrave, T. L. Meyer, and Daniel M. Larson 


\section{Winter Grazing System and Supplementation of Beef Cows During Late Gestation Influence Heifer Progeny}

\author{
Rick N. Funston \\ Jeremy L. Martin \\ Adam F. Summers \\ Don C. Adams \\ Jacqueline A. Musgrave \\ T. L. Meyer \\ Daniel M. Larson ${ }^{1}$
}

\section{Summary}

Effects of cow winter grazing system and supplementation on heifer progeny were evaluated. Cows grazed range (WR) or corn residue (CR) with (PS) or without (NS) supplement. Both PS and $C R$ increased weaning weight. Heifers from WR-NS dams weighed less at breeding and pregnancy diagnosis than WR-PS. Heifers from PS dams were younger at puberty, and pregnancy rate tended to be greater. Heifers from CR-PS dams gained the least and were least efficient. First-calf production and rebreeding were similar. There appear to be fetal programming effects of dam winter grazing system and supplementation on heifer progeny.

\section{Introduction}

Previous reports indicate no reproductive benefits from protein supplementation of spring calving beef cows grazing dormant Sandhills range during late gestation, despite the fact nutrient requirements are greater than nutrient content of the grazed forage. Supplementation of the dam during late gestation increases progeny weaning BW and increases fertility of heifer progeny. A study with steer mates to heifers utilized in the current study found late gestation supplementation altered post-weaning growth, carcass composition, and calf health in the feedlot, potentially through fetal programming.

The fetal programming hypothesis states postnatal growth and physiology can be influenced by stimuli experienced in utero. Previous research utilizing the same cowherd indicates dam protein supplementation increases heifer BW and fertility. There is potential for maternal nutrition to affect not only cow productivity but lifelong productivity of the heifer calf.

The objective of the current study was to determine the effects of grazing dormant Sandhills range or corn crop residue, with or without supplementation, on gain, feed efficiency, and reproduction in heifer-calf progeny.

\section{Procedure}

\section{Cow and Calf Management}

A three year study utilized composite Red Angus x Simmental cows and their progeny at Gudmundsen Sandhills Laboratory (GSL), Whitman, Neb. (preweaning data collection) and West Central Research and Extension Center (WCREC), North Platte, Neb. (postweaning data collection). Cows were used in a completely randomized design with a $2 \mathrm{x}$ 2 factorial arrangement of treatments to determine effects of grazing dormant Sandhills winter range (WR) or corn crop residue $(\mathbf{C R})$ and receiving CP supplement (PS) or no supplement (NS) on cow and heifer progeny performance. One hundred nine pregnant, spring-calving cows $(1,098$ $\pm 33 \mathrm{lb}$ initial BW) between 3 and 5 years of age were stratified by age and weaning BW of their previous calf and assigned randomly to treatment in year 1 . Cows remained on the same treatment for the length of the study, unless removed due to reproductive failure or injury. Pregnant 3-year-old cows were stratified by age and weaning BW of their previous calf and assigned randomly to treatment to replace cows removed from the study and to increase numbers as forage availability allowed. Data are reported for 2005 (109 cows), 2006 (114 cows), and 2007 (116 cows).

From late November until early March each year, cows grazing winter range were divided into four, 79acre upland pastures; two pastures received $\mathrm{CP}$ supplement, and two did not. From November to March each year, cows grazing CR were maintained in four fields; two fields received CP supplement, two did not. Cows were shipped approximately 52 miles to corn residue fields on Nov. 15th and returned to GSL on Feb. 25 th each year. Irrigated corn fields were planted in April and harvested in October, with an average annual yield of $200 \mathrm{bu} / \mathrm{ac}$. On a pasture or field basis, cows received the equivalent of $1 \mathrm{lb} /$ day of a 28\% CP (DM basis) supplement three times/week or no $\mathrm{CP}$ supplement from Dec. 1 until Feb. 28 on WR, or until Feb. 25th on CR. The supplement contained $62.0 \%$ dried distillers grains plus solubles, $11 \%$ wheat middlings, $9.0 \%$ cottonseed meal, 5.0\% dried corn gluten feed, $5.0 \%$ molasses, $2.0 \%$ urea, and $6.0 \%$ vitamin and trace mineral premix. The supplement was formulated to meet vitamin and trace mineral requirements of the 3-year-old cows and supply $80 \mathrm{mg} / \mathrm{head} /$ day monensin (Rumensin, Elanco Animal Health, Indianapolis, Ind.).

After winter grazing, cows were managed in a single group and fed hay harvested from subirrigated meadows and $\mathrm{CP}$ supplement. The average calving date was March 26. Cows returned to upland range in late May and remained in a single group throughout the breeding season until the subsequent winter grazing period. Cows were exposed to fertile bulls at a ratio of approximately 1 bull to 25 cows for 60 days each year, beginning on approximately June 5 .

(Continued on next page) 
Table 1. Effects of grazing winter range or corn residue and protein supplementation during the last trimester of gestation on heifer growth performance.

\begin{tabular}{|c|c|c|c|c|c|c|c|c|}
\hline \multirow[b]{3}{*}{ Trait } & \multicolumn{4}{|c|}{ Treatment $^{1}$} & \multirow[b]{3}{*}{ SEM } & \multirow{2}{*}{\multicolumn{3}{|c|}{ Treatment $P$-value ${ }^{2}$}} \\
\hline & \multicolumn{2}{|c|}{ WR } & \multicolumn{2}{|c|}{$\mathrm{CR}$} & & & & \\
\hline & PS & NS & PS & NS & & Sys & Supp & $\mathrm{S}^{\star} \mathrm{S}$ \\
\hline $\mathrm{n}$ & 6 & 6 & 6 & 6 & - & - & - & - \\
\hline Calf birth date, Julian d & 84 & 86 & 80 & 87 & 2 & 0.51 & 0.04 & 0.24 \\
\hline Calf birth BW, lb & 77.4 & 74.5 & 78.7 & 79.4 & 2.0 & 0.07 & 0.49 & 0.27 \\
\hline Calf weaning BW, lb & 507 & 481 & 516 & 509 & 13 & 0.03 & 0.04 & 0.17 \\
\hline Adj. calf weaning BW, lb & 478 & 454 & 478 & 485 & 9 & 0.02 & 0.15 & 0.03 \\
\hline Post-weaning ADG, lb & 1.10 & 1.08 & 1.06 & 1.10 & 0.11 & 0.86 & 0.72 & 0.25 \\
\hline Pre-breeding BW, lb & 712 & 679 & 710 & 717 & 33 & 0.17 & 0.24 & 0.11 \\
\hline Preg. diagnosis BW, lb & 809 & 780 & 811 & 825 & 24 & 0.06 & 0.54 & 0.09 \\
\hline
\end{tabular}

${ }^{1} \mathrm{WR}=$ dams grazed dormant winter range during late gestation; CR = dams grazed corn residue during late gestation; PS = dams supplemented with the equivalent of $1 \mathrm{lb} /$ day $28 \% \mathrm{CP}$ cake during late gestation; NS = dams not supplemented.

${ }^{2}$ Sys = winter grazing system main effect; Supp = protein supplementation main effect; $\mathrm{S}^{\star} \mathrm{S}=$ winter grazing system by protein supplementation treatment interaction.

\section{Heifer Calf Management}

Treatments included only dam winter grazing system and late gestation CP supplementation; no further treatments were applied to calves. Approximately 14 days following weaning, calves were transported to the WCREC, North Platte, Neb. Heifers remained in a single group for approximately 55 days following transport to the WCREC, and grazed a dormant winter pasture. Subsequently, heifers were offered a diet containing $20 \%$ wet corn gluten feed (WCGF) and $80 \%$ prairie hay (DM basis) ad libitum for 45 days. Interim BW and blood samples were collected every 10-11 days. Heifers from WR cows in year 1 and a subset of heifers from WR and CR dams in years 2 and 3 were assigned randomly to one of four pens containing Calan individual feeding systems (American Calan, Northwood, N.H.) to evaluate individual feed efficiency.

After a 30-day adaptation and training period, heifers were individually fed for a minimum of 84 days. Heifers were exposed to ambient temperature and light conditions. Threeday consecutive BW were taken at the beginning and end of the feeding period following a five day limit feeding period.

Following completion of the individual feeding period in early May each year, heifers returned to GSL.
Heifers were exposed to bulls (1:25; bull:heifer) for 45 days. Estrus was synchronized with a single injection of PGF $_{2 \alpha}$ administered 108 hours after bulls were placed with the heifers. Pregnancy diagnosis was performed via transrectal ultrasonography approximately 45 days following the breeding season.

\section{Statistical Analysis}

As treatments were applied on a field basis, winter pasture ( $\mathrm{n}=4$ /year) or corn residue field ( $n=4 /$ year) were considered the experimental units for heifer performance and reproductive data. In addition, $\mathrm{CP}$ was or was not provided to two winter pastures and two corn residue fields per year ( $n=4 / C P$ treatment/year). Data were analyzed using PROC MIXED of SAS (SAS Inst., Inc., Cary, N.C.). The statistical model included winter grazing system, CP supplementation, and the interaction. Cow age was included as a covariate for heifer calf data collected until weaning, where it represented a significant source of variation. Pasture nested with the effect of year $\mathrm{x}$ grazing treatment $\mathrm{x} C \mathrm{CP}$ treatment was included as a random variable in all analyses. In addition, pen nested within rep $\mathrm{x}$ year was included for data collected during and immediately after individual feeding, including gain, feed efficiency, and first season reproductive data.

\section{Results}

\section{Heifer Performance and Reproduction}

Heifer performance data are displayed in Table 1. Dams receiving PS calved four days earlier $(P=0.04)$ than NS cows; however, birth date was unaffected $(P=0.51)$ by winter development system. Cows grazing $\mathrm{CR}$ tended to give birth to heavier $(P=0.07)$ calves than WR cows, but PS did not affect $(P=0.49)$ calf birth $B W$. Heifer progeny weaning BW and adjusted weaning $\mathrm{BW}$ were greater $(P \leq 0.04)$ if the dam grazed CR. Adjusted weaning BW was lowest $(P=0.03)$ if the dam received NS while grazing WR. Weaning BW of steer mates from dams grazing WR with NS was lower than all other treatment groups. Supplementation appears to be necessary to attain maximal production of offspring from dams grazing WR.

Neither PS nor winter development system affected $(P>0.10)$ heifer ADG from weaning until the time they entered the Calan gates, or from weaning until breeding. There does not appear to be any compensatory gain of heifers from WR-NS dams, which supports a fetal programming hypothesis indicating a potential physiologic or genetic change in growth not remedied by dietary changes. Heifers from dams previously grazing CR with PS had a lower 
Table 2. Effects of grazing winter range or corn residue and protein supplementation during the last trimester of gestation on heifer reproduction.

\begin{tabular}{|c|c|c|c|c|c|c|c|c|}
\hline \multirow[b]{3}{*}{ Trait } & \multicolumn{4}{|c|}{ Treatment $^{1}$} & \multirow[b]{3}{*}{ SEM } & \multirow{2}{*}{\multicolumn{3}{|c|}{ Treatment $P$-value ${ }^{2}$}} \\
\hline & \multicolumn{2}{|c|}{ WR } & \multicolumn{2}{|c|}{ CR } & & & & \\
\hline & PS & NS & PS & NS & & Sys & Supp & $\mathrm{S}^{*} \mathrm{~S}$ \\
\hline $\mathrm{n}$ & 6 & 6 & 6 & 6 & - & - & - & - \\
\hline Age at puberty, days & 355 & 370 & 348 & 361 & 9 & 0.32 & 0.09 & 0.95 \\
\hline BW at puberty, lb & 615 & 619 & 626 & 635 & 24 & 0.50 & 0.72 & 0.90 \\
\hline Pubertal, \% & 91 & 74 & 79 & 84 & 7 & 0.71 & 0.38 & 0.11 \\
\hline Pregnant, \% & 91 & 77 & 88 & 83 & 7 & 0.96 & 0.13 & 0.45 \\
\hline
\end{tabular}

${ }^{1} \mathrm{WR}=$ dams grazed dormant winter range during late gestation; $\mathrm{CR}=$ dams grazed corn residue during late gestation; PS = dams supplemented with the equivalent of $1 \mathrm{lb} /$ day $28 \% \mathrm{CP}$ cake during late gestation; NS = dams not supplemented.

${ }^{2}$ Sys $=$ winter grazing system main effect; Supp = protein supplementation main effect; $S^{*} S=$ winter grazing system by protein supplementation treatment interaction.

$(P=0.03)$ ADG during the individual feeding period than all other heifers. Pre-breeding BW of WR-NS heifers tended to be lower $(P=0.11)$ than other treatments. The reduced BW at weaning appears to be maintained to pre-breeding, which agrees with previous research. Post-weaning ADG was similar $(P \geq 0.25)$ among treatments resulting in continued lower $(P=0.09) \mathrm{BW}$ at pregnancy diagnosis for WR-NS heifers, which is similar to previous findings. Steer progeny mates from cows receiving NS during gestation displayed more illness during post-weaning development than counterparts from PS dams. However, there was no effect $(P \geq 0.21)$ of winter system or PS on illness between birth and weaning or between weaning and breeding in heifer progeny.

First season reproductive data for heifer progeny are presented in Table 2. Heifers from dams receiving PS during late gestation tended $(P=0.09)$ to be younger at puberty than heifers from dams receiving NS; however, age at puberty was not affected $(P=0.32)$ by winter development system. Body weight at puberty was similar $(P \geq 0.50)$ among treatments. There also tended $(P=0.11)$ to be fewer heifers pubertal at breeding from dams previously grazing WR with NS which may be at least partially due to the lower BW at this time, as reducing $\mathrm{BW}$ at breeding reduces the number of heifers attaining puberty by breeding. Potentially related to pubertal status, heifers from NS dams tended $(P=0.13)$ to have lower pregnancy rates during the 45-day breeding season. Martin et al. (2007, Journal of Animal Science, 85:841-847) also reported providing PS to dams grazing WR improves subsequent pregnancy rate of heifer progeny. In the current study, pubertal status and pregnancy were modified by dam nutrition. Thus, these and previous data provide evidence of a fetal programming effect on reproduction. Winter development system did not affect final pregnancy rate $(P=0.96)$.

\section{Heifer Feed Efficiency}

Dry matter intake was similar $(P \geq 0.17)$ for heifers born to dams previously grazing WR or CR with or without PS. The ADG of heifers from dams grazing CR with PS was lower $(P=0.03)$ during the individual feeding period, compared to all other heifers. Thus, heifers from CR-PS dams gained less efficiently (G:F; $P=0.04)$ than heifers from dams in other treatment groups. In contrast, there were no differences $(P>0.10)$ in efficiency when expressed as RFI. Heifers from CR-PS dams represent the most adequately nourished group while heifers from WR-NS dams are the most restricted. This provides evidence for an efficiency adjustment in response to fetal environment, whereby heifer fetuses exposed to restricted nutrients (i.e., nonsupplemented dams) during gestation actually become more efficient in later life.

\section{Heifer Progeny Calf Production}

Heifer BW and BCS prior to calving were similar $(P \geq 0.14)$ among treatment groups. Birth date, birth $\mathrm{BW}$, and percentage of calves born in the first 21 days were also similar $(P \geq 0.29)$ among treatment groups. Prior to the second breeding season, heifers from dams previously grazing WR with NS tended $(P=0.09)$ to have lower BW than other treatment groups; however, BCS was not different $(P \geq 0.16)$. As heifer BW prior to calving was similar, the difference in BW prior to the second breeding season may indicate a difference in nutrient partitioning among treatment groups during the early postpartum period. This hypothesis is supported by the observation that at weaning, heifer BW and BCS were similar among treatment groups $(P \geq 0.20)$. Weaning BW and 205day adjusted BW of calves born to heifer progeny were similar $(P \geq 0.28)$ among treatments. Similar to previous data, reducing pre-breeding BW by either post-weaning ADG restriction or modulation of late gestation dam nutrition may impact first pregnancy outcome; pregnancy rate after the second breeding season was similar $(P \geq 0.97)$ among treatments.

\footnotetext{
${ }^{1}$ Rick N. Funston, associate professor of Animal Science, West Central Research and Extension Center, North Platte, Neb.; Jeremy L. Martin, former graduate student; Adam F. Summers, graduate student; Don C. Adams, director, West Central Research and Extension Center; Jacqueline A. Musgrave, research technician, Gudmundsen Sandhills Laboratory, Whitman, Neb.; T. L. Meyer, research technician, West Central Research and Extension Center; Daniel M. Larson, former graduate student.
} 